\title{
Chemical composition, phytotoxicity and cytogenotoxicity of essential oil from leaves of Psidium guajava L. cultivars
}

\author{
Composição química, fitotoxicidade e citogenotoxicidade do óleo essencial de follhas de cultivares de \\ Psidium guajava L.
}

Composición química, fitotoxicidad y citogenicidad del aceite esencial de hojas de cultivares de

\section{Psidium guajava L.}

Loren Cristina Vasconcelos

ORCID: https://orcid.org/0000-0002-0268-8529 Federal University of Espírito Santo, Brazil

E-mail: loren-vasconcelos@ hotmail.com

Esdras de Souza Santos

ORCID: https://orcid.org/0000-0002-4505-6484 Federal University of Espírito Santo, Brazil E-mail: esdrass.santos@outlook.com

Luiza Alves Mendes

ORCID: https://orcid.org/0000-0002-5252-0222

Federal University of Espírito Santo, Brazil

E-mail: luizavargasmendes@hotmail.com

Marcia Flores da Silva Ferreira

ORCID: https://orcid.org/0000-0003-1541-6634 Federal University of Espírito Santo, Brazil E-mail: mfloressf@gmail.com

Milene Miranda Praça Fontes

ORCID: https://orcid.org/0000-0001-7738-9518

Federal University of Espírito Santo, Brazil

E-mail: milenemiranda@yahoo.com.br

\begin{abstract}
Natural products with biological activity, such as essential oils, can be used in the search for and development of ecological herbicides as an alternative to reduce the damage caused by synthetic herbicides. This work to aimed to determine the chemical composition and phytotoxic properties of the essential oils, at concentrations of 3000, 1500, 750,375 and $187.5 \mu \mathrm{g} / \mathrm{mL}$, of four cultivars of Psidium guajava (guava) evaluated on germination and root growth of plant models Lactuca sativa and Sorghum bicolor, as well as in the L. sativa cell cycle. Exposure to essential oils reduced germination and root growth in bioassays, especially at the highest concentration $(3000 \mu \mathrm{g} / \mathrm{mL})$. The essential oils interfered in the normal dynamics of the cell cycle of $L$. sativa at most concentrations, causing a decrease in the mitotic index and increasing of chromosomal alterations, evidencing aneugenic and clastogenic action. The biological activity of the oils was associated with the presence of sesquiterpenes and monoterpenes found here, such as caryophyllene oxide, (E) -caryophyllene, and limonene. Thus, the essential oils of cultivars of guava demonstrated the promising potential for use as natural herbicides.
\end{abstract}

Keywords: Biological activity; Bioherbicides; Chromosome; Plant bioassay; Terpenes; Mitotic index.

\section{Resumo}

Produtos naturais com atividade biológica, como os óleos essenciais, podem ser utilizados na busca e desenvolvimento de herbicidas ecológicos como alternativa para reduzir os danos causados pelos herbicidas sintéticos. Este trabalho teve como objetivo determinar a composição química e propriedades fitotóxicas de óleos essenciais, nas concentrações de 3000, 1500, 750, 375 e 187,5 $\mu \mathrm{g} / \mathrm{mL}$, de quatro cultivares de Psidium guajava (goiaba) avaliadas na germinação e crescimento radicular das plantas modelos Lactuca sativa e Sorghum bicolor, bem como no ciclo celular de L. sativa. A exposição aos óleos essenciais reduziu a germinação e o crescimento radicular nos bioensaios, especialmente na concentração mais elevada $(3000 \mu \mathrm{g} / \mathrm{mL})$. Os óleos essenciais interferiram na dinâmica normal do ciclo celular de L. sativa na maioria das concentrações, causando diminuição do índice mitótico e aumento das alterações cromossômicas, evidenciando ação aneugênica e clastogênica. A atividade biológica dos óleos foi associada à presença de sesquiterpenos e monoterpenos aqui encontrados, como óxido de cariofileno, (E) cariofileno e limoneno. Assim, os óleos essenciais de cultivares de goiaba demonstraram potencial promissor para uso como herbicidas naturais. 
Palavras-chave: Atividade biológica; Bioherbicidas; Cromossomos; Bioensaio vegetal; Terpenos; Índice mitótico.

\section{Resumen}

Los productos naturales con actividad biológica, como los aceites esenciales, pueden utilizarse en la búsqueda y desarrollo de herbicidas ecológicos como alternativa para reducir el daño causado por los herbicidas sintéticos. Este trabajo tuvo como objetivo determinar la composición química y propiedades fitotóxicas de los aceites esenciales, a concentraciones de 3000, 1500, 750, 375 y $187.5 \mu \mathrm{g} / \mathrm{mL}$, de cuatro cultivares de Psidium guajava (guayaba) evaluados en la germinación y crecimiento radicular de modelos vegetales Lactuca sativa y Sorghum bicolor, así como en el ciclo celular de L. sativa. La exposición a los aceites esenciales redujo la germinación y el crecimiento de las raíces en los bioensayos, especialmente a la concentración más alta $(3000 \mu \mathrm{g} / \mathrm{mL})$. Los aceites esenciales interfirieron en la dinámica normal del ciclo celular de L. sativa en la mayoría de concentraciones, provocando disminución del índice mitótico y aumento de alteraciones cromosómicas, evidenciando acción aneugénica y clastogénica. La actividad biológica de los aceites se asoció con la presencia de sesquiterpenos y monoterpenos que se encuentran aquí, como el óxido de cariofileno, (E) -cariofileno y limoneno. Así, los aceites esenciales de cultivares de guayaba demostraron el potencial prometedor para su uso como herbicidas naturales.

Palabras clave: Actividad biológica; Bioherbicidas; Cromosoma; Bioensayo vegetal; Terpenos; Índice mitótico.

\section{Introduction}

The use of synthetic herbicides in crop fields has been questioned due to the environmental impact and toxicological implications caused to farmers and consumers by the application of these products (Jabran et al., 2015; Ribas \& Matsumura, 2009). Additionally, weeds are becoming increasingly resistant due to the few modes of action present in herbicides, increasing the demand for more efficient, sustainable, and safe active ingredients (Dayan \& Duke, 2014).

Allelopathy is a biochemical strategy in which plants negatively influence or benefit the growth and development of other plants by the action of allelochemicals (secondary metabolites) released into the environment (Inderjit et al., 2011; Rice, 2012). These compounds found in natural products, such plant extracts and essential oils, are biodegradable and have a wide structural diversity with a wide variety of modes of action (Jana \& Biswas, 2011). In this context, natural substances that have allelopathic activity have already been recognized as an alternative for the control of agricultural pests and the development of new herbicides (Dayan \& Duke, 2014).

Essential oils are a complex mixture of volatile and lipophilic substances produced by secondary metabolism of individual plants. They have associated the adaptations to the environment, like the attraction of pollinators and seed dispersers, interactions with microorganisms and other plants, protection against predators, and abiotic stresses (Boaro et al., 2019). The literature presents several works that report on the biological activity of essential oils as herbicides, pesticides and biocidal agents (Giunti et al., 2021; Grul'ová et al., 2020; Hazrati et al., 2017; Navarro-Rocha et al., 2020; Rajkumar et al., 2020; Taban et al., 2020). These effects are related to the complex interaction between the compounds present in essential oil, being mostly monoterpenes and sesquiterpenes. These interactions allow each compound to modulate or alter the effects of other ones (Sharifi-Rad et al., 2017).

Myrtaceae is an important family of pantropical plants with some species rich in essential oils (Beech et al., 2017; Wilson, 2010) known for its allelopathic potential and the biological activity (Caputo et al., 2020; Durazzini et al., 2019; Habermann et al., 2017; Scalvenzi et al., 2017). The genus Psidium is one of the most representative of the family with about more than 150 species of plants (Hayes, 1953). However, little is known about the allelopathic activity of its species, especially with regard to essential oils. Recently, studies of essential oils from different species of the genus Psidium, Psidium cattleianum (araçá-vermelho), P. myrtoides (araçá-roxo), P. friedrichsthalianum (araçá-azedo), P. gaudichaudianum (araçá) and $P$. guajava (guava), reported the ability of these oils to inhibit the germination of seeds and the growth of other plants, as Lactuca sativa, Sorghum bicolor and Lycopersicum esculentum, being considered potential sources of natural herbicides (Almeida et al., 2019; Vasconcelos et al., 2019).

Psidium guajava L. (Myrtaceae), popularly known as guava, is one of the most studied species of the genus. With 
pleasant taste and high nutritional value rich in antioxidant compounds and also has antimicrobial properties, guava stands out in the food industry and in popular medicine (Shu et al., 2012). Studies with the essential oil of P. guajava leaves showed the antimicrobial, antiproliferative, antiparasitic, anti-inflammatory, antioxidant and cytotoxic effects of the species (Chaturvedi et al., 2019; Jerônimo et al., 2021; Lee et al., 2013; Weli et al., 2019).

Essential oils extracted from leaves of different $P$. guajava cultivars grown under the same conditions and in similar environments have shown differential larvicidal activity on the Aedes aegypti L. (Mendes et al., 2017). It has also been shown that the genetic and environmental factor are an important constituent of the composition of the essential oils of guava (Souza et al., 2017). These studies show that the use of these oils can be enhanced by choosing the appropriate genotype. Different genotypes can promote variation in the composition of essential oils, leading to different properties and, therefore, are of great interest in the management and control of weeds.

Contemplating the above, this work aimed to (a) investigate of the chemical constituents of the essential oil from the leaves from four guava cultivars (Cortibel Branca LG, Cortibel VII, Paluma and Século XXI), (b) evaluate the allelopathic effects on the germination and initial development of the model plants Lactuca sativa L. and Sorghum bicolor (L.) Moench, and (c) assess of the cytogenotoxicity of the respective oils on the cell cycle of L. sativa.

\section{Methodology}

\subsection{General experimental procedures}

The chromatographs used in essential oil analysis were by gas chromatography with flame ionization detector (GCFID) model Shimadzu GC-2010 Plus and gas chromatography coupled to mass spectrometry (GC-MS) model Shimadzu GCMS-QP2010 SE. Seeds of L. sativa (commercial cultivar Crespa Grand Rapids - TBR) obtained from ISLA Sementes and S. bicolor (commercial cultivar Al Precious) from BRSEEDS. The 2\% (w.v) acetic orcein dye was purchased from SigmaAldrich.

\subsection{Plant material}

Leaves were collected from cultivars Cortibel Branca LG (C4), Paluma (PAL), Século XXI (SEC), and the superior genotype of guava Cortibel VII (C7) in the experimental area of the Federal University of Espírito Santo in Alegre, ES- Brazil, altitude $254 \mathrm{~m}$, coordinates $20^{\circ} 45^{\prime} 50^{\prime \prime} \mathrm{S} 41^{\circ} 31^{\prime} 58^{\prime \prime} \mathrm{W}$, subtropical climate by Köppen-Geiger climate classification: Cwa, in the morning at breast height $(1.3 \mathrm{~m})$ and around the canopy diameter. The experiment followed a randomized block design (RBD) with three blocks. Samples were collected around treetop using young and old leaves from all plants and blocks in order to randomize any differences between them. After, the leaves were dried in the shade and at room temperature for one week.

\subsection{Chemical characterization of essential oils}

The essential oils were extracted from $500 \mathrm{~g}$ of dry leaves of the C4, C7, PAL, and SEC guava cultivars by hydrodistillation technique in Clevenger apparatus. The samples were divided and placed in two round-bottom volumetric flasks of $2000 \mathrm{~mL}$ with distilled water and distilled for approximately $4 \mathrm{~h}$. The extractions used about $250 \mathrm{~g}$ of leaves in approximately $1000 \mathrm{~mL}$ of water. The hydrolate obtained was centrifuged at $5000 \mathrm{RPM}$ (rotations per minute) for 5 min to separate the aqueous and oily phases. The essential oils (supernatant) were removed with a Pasteur pipette and stored in amber glass bottles in a freezer at $-20^{\circ} \mathrm{C}$.

The chemical composition of the essential oils was determined by gas chromatography coupled to mass spectrometry (GC-MS) and the quantification by gas chromatography with flame ionization detector (GC-FID). The analyses were 
performed using a fused silica capillary column $(30 \mathrm{~m} \times 0.25 \mathrm{~mm})$ with the stationary phase RTX® $-5 \mathrm{MS}(0.25 \mu \mathrm{m}$ internal diameter). Helium was used as the carrier gas with flow and linear rate of $2.80 \mathrm{~mL}$ min-1 and $50.80 \mathrm{~cm} \mathrm{seg-1}$ (GC-FID); and $1.98 \mathrm{~mL}$ min-1 and $50.90 \mathrm{~cm}$ seg-1 (GC-MS), respectively. The temperature of the injector was $220^{\circ} \mathrm{C}$ and FID and MS detector temperature of $240{ }^{\circ} \mathrm{C}$ and $200{ }^{\circ} \mathrm{C}$, respectively. The initial temperature of the furnace was $40^{\circ} \mathrm{C}$, which remained for $3 \mathrm{~min}$ and then gradually increased by $3^{\circ} \mathrm{C} / \mathrm{min}$ until reaching $180^{\circ} \mathrm{C}$. Chemical constituents were identified by mass spectra obtained compared with data of spectral library, retention index (RI), and literature data (Adams, 2007; NIST, 2011). The GCMS and GC-FID analyses were performed as described by Mendes et al. (2017).

\subsection{Phytotoxicity analyses}

The phytotoxicity effects of the essential oils of the cultivars of $P$. guajava was evaluated against the selected plants, L. sativa (dicot) and S. bicolor (monocot), in laboratory bioassays. These model plants have been widely used to verify the effects of chemical compounds on germination and initial development, as they are highly sensitive to toxic substances, have fast germination and low cost (Alves et al., 2018; Vasconcelos et al., 2019). The solutions of essential oils of P. guajava were prepared by intense mixed and agitation with the solvent composed of distilled water, acetone ( $2 \% \mathrm{v} . \mathrm{v})$, and Tween $80 \circledR$ ( $0.05 \%$ v.v). Five oil concentrations were tested: 3000, 1500, 750, 375 and $187.5 \mu \mathrm{g} / \mathrm{mL}$. The solvent used in the preparation of the solutions was previously compared with water, and both presented the same statistical results. So, the water was applied as a negative control in the analysis, omitting the solvent. The herbicide glyphosate was used as positive control, at $0.01 \%$ (v.v), the same concentration recommended for commercial use. Petri dishes were lined with filter paper and treated with $2 \mathrm{~mL}$ of the solutions of essential oils and negative and positive controls. In each treatment, 25 seeds of each plant model were used, with five replications each. The plates were wrapped with plastic film and incubated in a germination chamber (BOD), under photoperiod with $16 \mathrm{~h}$ of light, at $24 \pm 2^{\circ} \mathrm{C}$ where they remained for $120 \mathrm{~h}$.

The germination percentage (GP) - number of germinated seeds after $48 \mathrm{~h}$ of exposure to the treatments, calculated by the ratio between the number of germinated seeds times 100 divided by the total number of exposed seeds per repetition; germination speed index (GSI) - number of germinated seeds counted every $8 \mathrm{~h}$ during the first $48 \mathrm{~h}$ of exposure to the treatments, calculated by formula $(\mathrm{N} 1 * 1)+(\mathrm{N} 2-\mathrm{N} 1) * 1 / 2+(\mathrm{N} 3-\mathrm{N} 2) * 1 / 3+\ldots(\mathrm{Ny}-(\mathrm{Ny}-1)) * 1 / \mathrm{y}$, where: Ny refers to the number of seeds germinated within a given period; $\mathrm{y}$ : represents the total number of time intervals; and root growth (RG) measured (in $\mathrm{mm}$ ) with the aid of a digital caliper after $48 \mathrm{~h}$ of exposure to the treatments of model plants exposed to the essential oils of $P$. guajava cultivars were evaluated.

\subsection{Cytotoxicity analyses}

To evaluate the cytotoxicity of the essential oils of the different guava cultivars, meristematic cell slides of $L$. sativa (lettuce) roots were prepared. Only lettuce roots were used because they are considered a suitable model for microscopic analysis (cytotoxic analysis) to test the toxic effect of chemical compounds (Silveira et al., 2017). In addition, lettuce is highlighted because it presents high proliferative activity, rapid growth, high number of seeds, large chromosomes, high sensitivity to mutagenic and genotoxic compounds, and easily manipulated roots (Andrade-Vieira et al., 2014; Aragão et al., 2017). Lettuce roots were collected at $48 \mathrm{~h}$ of exposure in the phytotoxicity assays and fixed in ethanol: acetic acid (3:1) and stored at $-20^{\circ} \mathrm{C}$ to perform the analysis. The fixer was changed once after $10 \mathrm{~min}$ and once after $24 \mathrm{~h}$. Lettuce is one of the most common species used in the evaluation of the toxic effects of substances. Besides the advantages mentioned earlier in this work, it presents a small number of chromosomes $(2 \mathrm{n}=2 \mathrm{x}=18)$ with easy visualization under the microscope, and roots easy to manipulate for slide preparation and microscopic analyses (Matoba et al., 2007; Silveira et al., 2017).

The previously fixed roots were washed with distilled water and hydrolyzed in $5 \mathrm{~N} \mathrm{HCl}$ for 18 min at room 
temperature. We prepare the slides using the crushing technique, stained with $2 \%$ (w.v) acetic orcein, before being covered by a coverslip and observed under the light microscope. The mitotic index (MI) was obtained by observation of 5000 cells in mitosis per treatment and controls (1000 cells per lamina). The frequency of nuclear alterations (NA) and chromosomal alterations (CA) in the cells observed was also evaluated according to Pinheiro et al. (2015).

\subsection{Statistical analyses}

The experiments were conducted in a completely randomized design (CRD) with five replications for each treatment $(3000,1500,750,375$, and $187.5 \mu \mathrm{g} / \mathrm{mL}$ ) and control (distilled water and glyphosate). The results of the analyses on phytoand cytogenotoxicity were further inspected in an analysis of variance (ANOVA), and the resulting mean values in a Dunnett's test at 5\% significance for compared the treatments with the controls. All statistical analyses were performed using the $\mathrm{R}$ computing environment (R Development Core Team, 2020).

\section{Results and Discussion}

\subsection{Chemical characterization of essential oils}

Twenty-nine compounds were identified in the essential oils from leaves of guava cultivars in GC-MS analyses. Were only considered compounds with a relative area above $1 \%$ after normalization, which accounted for $96.8 \%$ to $98.4 \%$ of the total compounds present in the four cultivars. The compounds that had a relative area above $10 \%$ were considered major compound; these are presented in Table 1 adapted from Mendes et al. (2017). Our analyses showed that most of the chemical constituents of the all essential oils were sesquiterpenes, which more of $70 \%$ in their composition and smaller amounts of monoterpenes, varying between $1.4 \%$ and $22.9 \%$ (Table 1). Other chemical characterizations of essential oils of P. guajava with the same terpenic nature were found in others works (Satyal et al., 2015; Souza et al., 2017).

The oil of the cultivar SEC was the only one constituted of $100 \%$ sesquiterpenes, of which 51,5\% were hydrogenated and 48,5\% oxygenated. Among the major compounds found, stand out (E)-caryophyllene (26.6\%) and caryophyllene oxide (15.5\%) in SEC. Similar to SEC, PAL oil showed (E)-caryophyllene (19.4\%) and caryophyllene oxide (16.6\%) in the highest amounts. The chromatographic profile of $\mathrm{C} 4$ presented the highest concentration of monoterpenes among all oils with $23,7 \%$ limonene (17.8\%) and $\beta$-bisabolol (19.5\%) were majority compounds. In the superior genotype $\mathrm{C} 7$, the most prominent compounds in the oil were $\alpha$-humulene (20.8\%), (E)-caryophyllene (19.8\%) and selin-11-en-4 $\alpha$-ol (10.9\%). The major compounds identified here (limonene, (E)-caryophyllene, $\alpha$-humulene, caryophyllene oxide, selin-11-en-4 $\alpha$-ol, and $\beta$ bisabolol) corresponded to chemical characterizations reported in other studies on essential oils of $P$. guajava (Khadhri et al., 2014; Soliman et al., 2016; Souza et al., 2017). 
Table 1. Chemical identification and relative peak area (\%) of the compounds present in the essential oils of four cultivars of Psidium guajava.

\begin{tabular}{|c|c|c|c|c|c|c|c|}
\hline \multirow{2}{*}{$\mathrm{N}$} & \multirow{2}{*}{ Compound $^{\mathrm{a}}$} & \multirow{2}{*}{ RIcal $^{\text {b }}$} & \multirow{2}{*}{$\operatorname{RItab}^{\mathrm{c}}$} & \multicolumn{4}{|c|}{ Cultivar / $\mathrm{A}_{\text {rel }}(\%)^{\mathrm{d}}$} \\
\hline & & & & SEC & PAL & $\mathrm{C} 4$ & $\mathrm{C} 7$ \\
\hline 1 & Benzaldehyde & 960 & 952 & - & - & 1.7 & - \\
\hline 2 & Limonene & 1028 & 1024 & - & - & 17.8 & - \\
\hline 3 & 1,8-Cineole & 1031 & 1026 & - & 8.4 & 5.1 & 4.1 \\
\hline 4 & $\alpha$-Terpineol & 1190 & 1186 & - & 1.4 & - & - \\
\hline 5 & $\alpha$-Copaene & 1375 & 1374 & 1.8 & 1.2 & - & - \\
\hline 6 & (E)-Caryophyllene & 1417 & 1417 & 26.6 & 19.4 & 7.6 & 19.8 \\
\hline 7 & Aromadendrene & 1438 & 1437 & 4.3 & 2.9 & - & - \\
\hline 8 & $\alpha-$ Humulene & 1452 & 1452 & 3.3 & 2.5 & - & 20.8 \\
\hline 9 & $\alpha$-Curcumene & 1484 & 1487 & - & - & 4.5 & - \\
\hline 10 & $\beta$-Selinene & 1486 & 1489 & 7.6 & 5.6 & - & 7.8 \\
\hline 11 & $\alpha-$ Selinene & 1495 & 1498 & 6.5 & 4.9 & 2.2 & 7.1 \\
\hline 12 & $\beta$-Bisabolene & 1509 & 1505 & - & - & 5.6 & - \\
\hline 13 & $\beta$-Himachalene & 1511 & 1500 & - & - & 2.9 & - \\
\hline 14 & B-Sesquiphellandrene & 1523 & 1521 & - & - & 2.8 & - \\
\hline 15 & $\alpha$-Bisabolene & 1533 & 1536 & - & - & 2.6 & - \\
\hline 16 & (E)-Nerolidol & 1566 & 1561 & 3.8 & 3.4 & 6.9 & 5.7 \\
\hline 17 & Caryophyllene oxide & 1582 & 1582 & 15.5 & 16.6 & 3.2 & 5.4 \\
\hline 18 & Ledol & 1600 & 1602 & 1.3 & 1.3 & - & - \\
\hline 19 & Humulene epoxide & 1608 & 1608 & - & - & - & 4.0 \\
\hline 20 & Selina-6-en-4-ol & 1612 & 1615 & - & - & 1.6 & - \\
\hline 21 & epi-Cubenol & 1629 & 1627 & 2.7 & 2.8 & 2.8 & - \\
\hline 22 & y-Eudesmol & 1632 & 1630 & 3.2 & 3.7 & - & 7.0 \\
\hline 23 & Aromadendrene epoxide & 1639 & 1639 & 8.1 & 9.2 & - & - \\
\hline 24 & $\tau-$ Cadinol & 1643 & 1640 & 1.6 & 1.6 & - & 4.5 \\
\hline 25 & $\alpha$-Muurolol & 1648 & 1644 & 1.8 & 1.9 & - & - \\
\hline 26 & Selin-11-en- $4 \alpha-$ ol & 1658 & 1658 & 6.7 & 7.4 & 3.5 & 10.9 \\
\hline 27 & $\beta$-Bisabolol & 1673 & 1674 & 2.7 & 2.4 & 19.5 & 1.3 \\
\hline 28 & $\alpha$-Bisabolol & 1685 & 1685 & - & - & 1,6 & - \\
\hline 29 & $(\mathrm{Z}, \mathrm{E})-\alpha$-Bergamotol & 1688 & 1690 & - & - & 4,9 & - \\
\hline \multicolumn{2}{|c|}{ Total Identified } & & & 97.5 & 96.6 & 96.8 & 98.4 \\
\hline \multicolumn{2}{|c|}{ Hydrocarbon monoterpenes } & & & - & - & 18.4 & - \\
\hline \multicolumn{2}{|c|}{ Oxygenated monoterpenes } & & & - & 10.1 & 5.3 & 4.2 \\
\hline \multicolumn{2}{|c|}{ Hydrocarbon sesquiterpenes } & & & 51.4 & 37.8 & 29.1 & 56.4 \\
\hline \multicolumn{2}{|c|}{ Oxygenated sesquiterpenes } & & & 48.6 & 52.1 & 45.5 & 39.4 \\
\hline \multicolumn{2}{|c|}{ Others } & & & - & - & 1.7 & - \\
\hline
\end{tabular}

${ }^{\mathrm{a}}$ Compounds listed in the elution order using column of Rtx ${ }^{\circledR}-5 \mathrm{MS}$. ${ }^{\mathrm{b}}$ Retention index calculated. ${ }^{\mathrm{c}}$ Tabulated retention index (Adams, 2007). ${ }^{\mathrm{d} C o m p o u n d s}$ were identified with areas related to $>1 \%$. Cultivars: Século XXI (SEC), Cortibel Branca LG (C4), Paluma (PAL) e Cortibel VII (C7).

Source: Authors.

In this study, the hydrogenated sesquiterpene (E)-caryophyllene was the main chemical constituent found in guava cultivars oils, appearing as a major component in three of the four oils evaluated. Differences in the chemical profile of essential oils are common in many works. The quantity and chemical composition of oils is influenced by several factors that can cause significant changes in the production of specialized metabolites. These can be determined by genetic characters, or by biotic and abiotic factors (Aslam et al., 2017; Souza et al., 2017). The stimuli resulting from the environment where the plant is located can redirect the metabolic route, leading to biosynthesis of different compounds, however genetic variations are very important factors for these variations in the composition of essential oils (Boaro et al., 2019). 


\subsection{Phytotoxicity effects}

The phytotoxic potential was tested of the essential oils of $P$. guajava cultivars by evaluating the inhibition of seed germination, germination speed index, and root growth of lettuce and sorghum. Phytotoxic analyzes in the model plants showed that for all oils, in general, the highest concentrations had the most significant effects on the evaluated variables, reducing them. $\mathrm{C} 7$ and $\mathrm{C} 4$ oils caused more evident effects. These oils significantly reduced the percentage germination of lettuce at 375,750 and $3000 \mu \mathrm{g} / \mathrm{mL}$ compared to the water, and of sorghum at $3000 \mu \mathrm{g} / \mathrm{mL}$ compared to both controls (water and glyphosate). SEC caused effects in percentage germination of lettuce only at $3000 \mu \mathrm{g} / \mathrm{mL}$, and sorghum at $750 \mu \mathrm{g} / \mathrm{mL}$, concerning glyphosate and water, respectively (Figure 1a, 2a, 3a, 4a).

Figure 1. Effect of Século XXI (SEC) essential oil on (a) germination, (b) germination speed index (GSI), and (c) root growth of Lactuca sativa and Sorghum bicolor. The lowercase letters above boxplots indicates significant differences. Boxplots followed by the letter a are statistically identical to water, boxplots followed by $b$ are statistically identical to glyphosate and boxplots not followed by letters are statistically different from water and glyphosate by Dunnett's test $(\mathrm{P}<0.05)$.
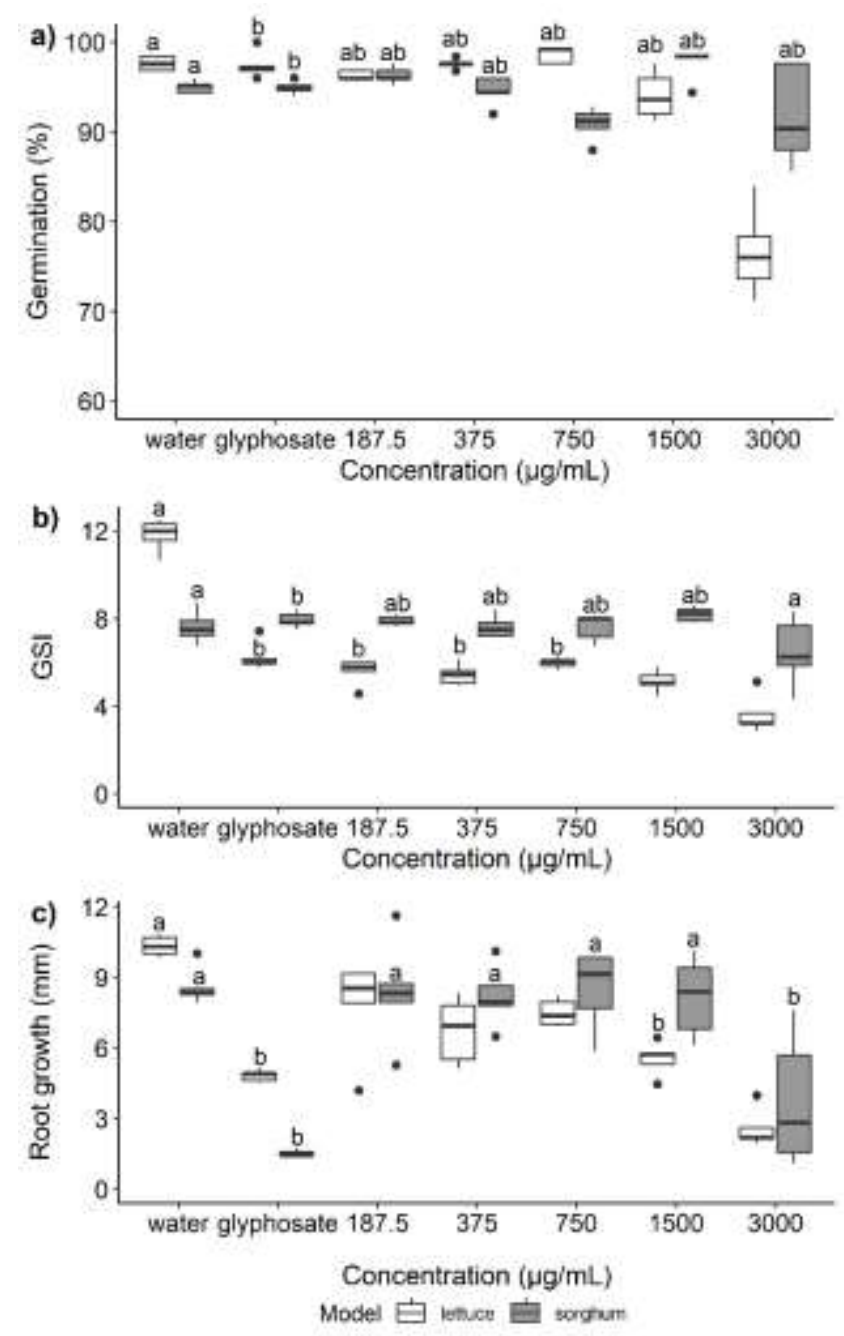

Source: Authors.

Regarding the GSI, all concentrations of the oils of the tested cultivars negatively interfered in the GSI of the lettuce seeds, presenting statistical similarity with the glyphosate, except for $187.5 \mu \mathrm{g} / \mathrm{mL}$ of C7 and $1500 \mu \mathrm{g} / \mathrm{mL}$ of SEC. In lettuce, SEC oil caused the highest inhibition in the GSI with a reduction of $69.35 \%$ at $3000 \mu \mathrm{g} / \mathrm{mL}$, whereas sorghum showed significant reduction only at $3000 \mu \mathrm{g} / \mathrm{mL}$ of $\mathrm{C} 4$ and $375 \mu \mathrm{g} / \mathrm{mL}$ of PAL, compared to the water (Figure 1b, 2b, 3b, 4b). 
Figure 2. Effect of Paluma (PAL) essential oil on (a) germination, (b) germination speed index (GSI), and (c) root growth of Lactuca sativa and Sorghum bicolor. The lowercase letters above boxplots indicates significant differences. Boxplots followed by the letter a are statistically identical to water, boxplots followed by b are statistically identical to glyphosate and boxplots not followed by letters are statistically different from water and glyphosate by Dunnett's test $(\mathrm{P}<0.05)$.
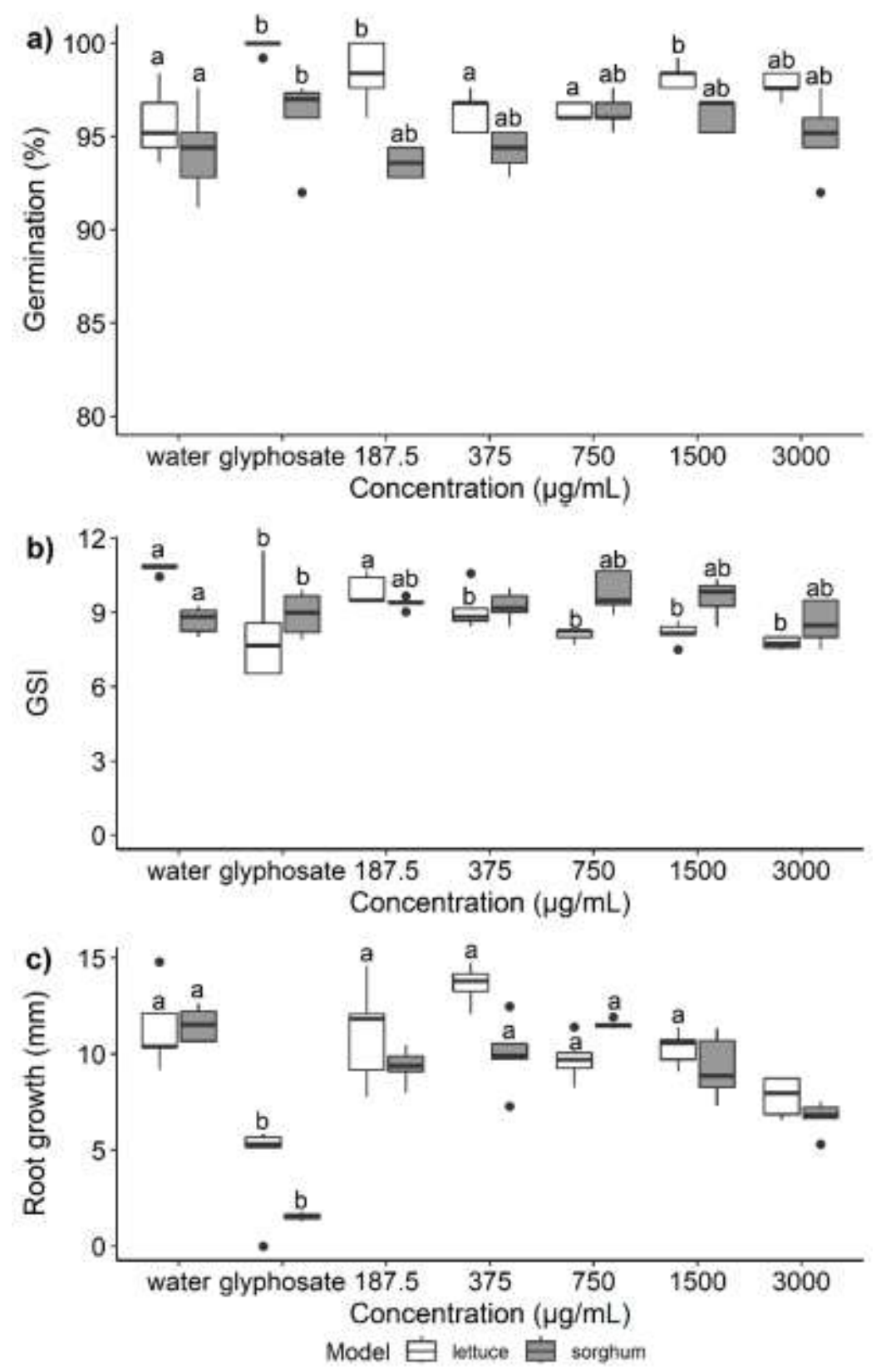

Source: Authors.

In RG evaluation, the roots of lettuce treated with essential oils of $\mathrm{C} 7$ and $\mathrm{C} 4$ presented drastic reduction. The effect of the concentrations was comparable to the glyphosate, except for the lowest concentration $(187.5 \mu \mathrm{g} / \mathrm{mL}) \mathrm{of} \mathrm{C} 4$. In sorghum, C7 oil interfered negatively in the root growth at 3000 and $1500 \mu \mathrm{g} / \mathrm{mL}$, while C4 oil caused a reduction of $47.29 \%$ at 3000 $\mu \mathrm{g} / \mathrm{mL}$ (Figure 1c, 2c). The seedlings of lettuce and sorghum also suffered negative effects on root growth from the oils of PAL and SEC. At a concentration of $3000 \mu \mathrm{g} / \mathrm{mL}$, the PAL and SEC oils caused a severe reduction of root growth in lettuce $(31.67 \%)$ and sorghum $(56.45 \%)$ in comparison to the water (Figure $3 \mathrm{c}, 4 \mathrm{c}$ ). 
Figure 3. Effect of Cortibel Branca LG (C4) essential oil on (a) germination, (b germination speed index (GSI), and (c) root growth of Lactuca sativa and Sorghum bicolor. The lowercase letters above boxplots indicates significant differences. Boxplots followed by the letter a are statistically identical to water, boxplots followed by b are statistically identical to glyphosate and boxplots not followed by letters are statistically different from water and glyphosate by Dunnett's test $(\mathrm{P}<$ $0.05)$.
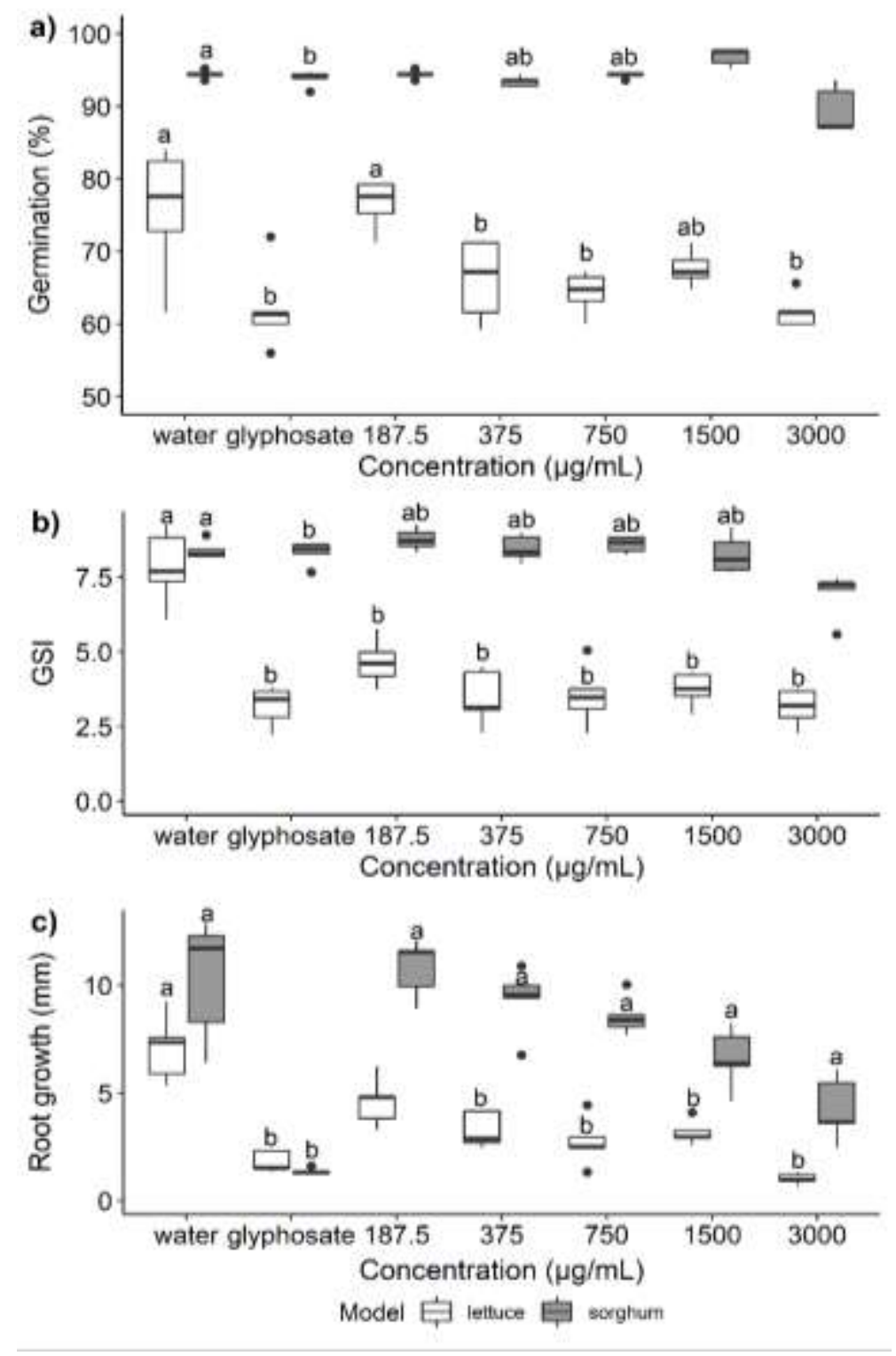

Source: Authors.

The chemical composition of essential oils provides clues about their phytotoxic effects. Based on the obtained results of bioassays involving germination and root growth of L. sativa and S. bicolor, we found that the oils affected the variables GP, GSI, and RG these models, principally in the highest concentration. These effects may be associated with the terpenic nature of essential oils. According to Harborne and Tomas-Barberan (1990), these substances in contact with the soil inhibit the development of other plants, causing decomposition, volatilization, leaching, and exudation of compounds present in the vegetable tissues. 
Figure 4. Effect of Cortibel VII (C7) essential oil on (a) germination, (b) germination speed index (GSI), and (c) root growth of Lactuca sativa and Sorghum bicolor. The lowercase letters above boxplots indicates significant differences. Boxplots followed by the letter a are statistically identical to water, boxplots followed by b are statistically identical to glyphosate and boxplots not followed by letters are statistically different from water and glyphosate by Dunnett's test $(\mathrm{P}<0.05)$.
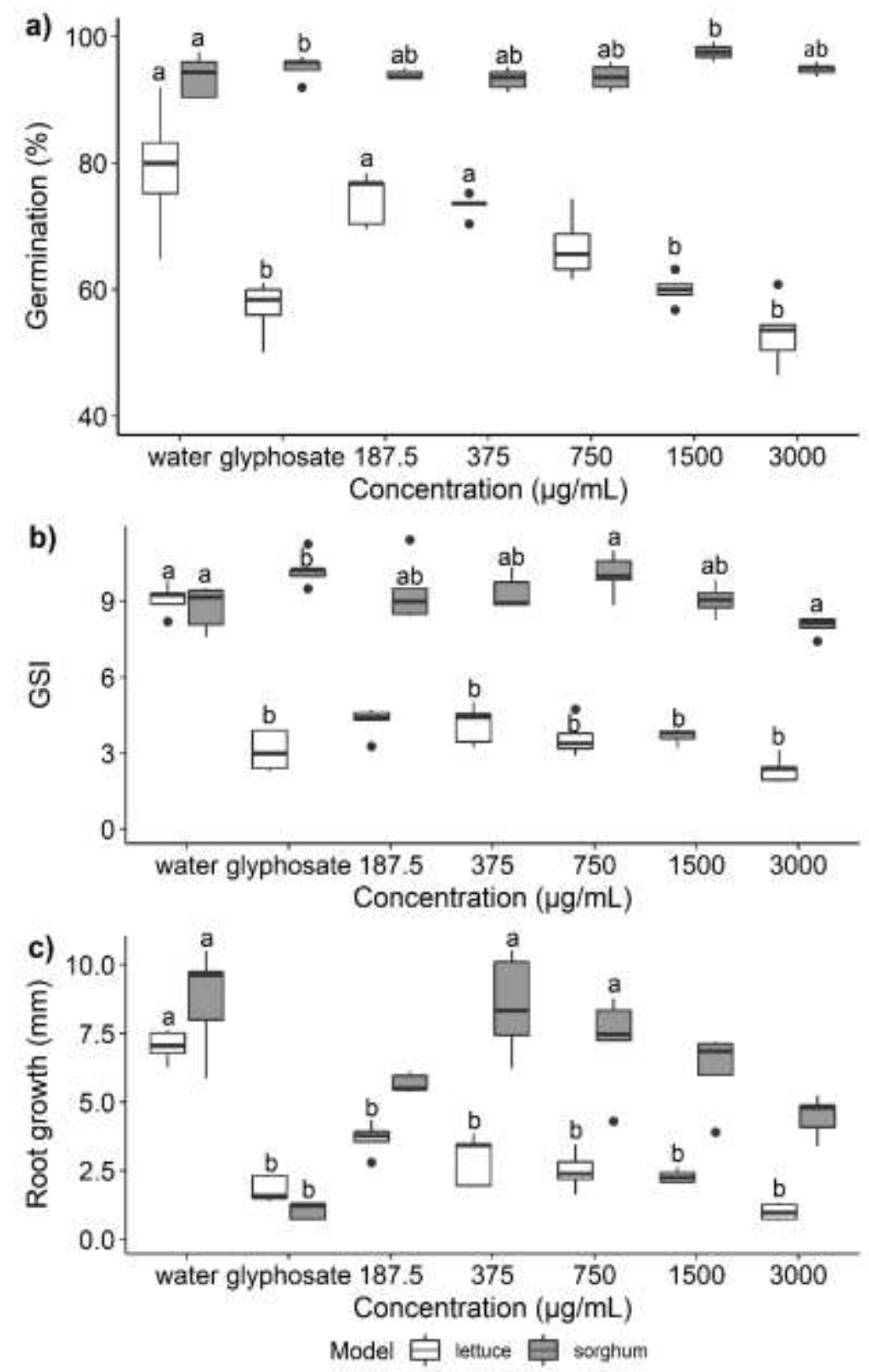

Source: Authors.

Among the terpenoids, the sesquiterpenes were the most abundant chemical constituents found in the essential oils of guava cultivars. They are considered a source of active compounds with important biological activity that can act as herbicides (Duke et al., 2000). (E)-caryophyllene, hydrocarbon sesquiterpene present in all essential oils evaluated, except for C4, have allelopathic effects reported for seedlings of Brassica campestris and Raphanus sativus (Ruilong et al., 2009). Phytotoxic and cytotoxic effects of the essential oil of Psidium species on L. sativa and S. bicolor were associated with the presence of (E)caryophyllene (Vasconcelos et al., 2019).

Caryophyllene oxide, which is a product of the oxidation of (E)-caryophyllene, oxygenated sesquiterpene found in all 
cultivars, was reported for its allelopathic potential, significantly affecting the germination and development of $L$. sativa (Dias et al., 2009). The sesquiterpenes to affect plant growth through oxidative stress in conjunction with effects on physiological processes (Duke \& Oliva, 2004). Effects on mitochondrial respiration, distribution, and organization of microtubules are also reported (Araniti et al., 2016; Ibrahim et al., 2013).

Monoterpenes are identified as compounds present in essential oils of plants with greater allelopathic potential, as Eucalyptus genus, influencing seed germination, and inhibition of root growth (Amri et al., 2013). The low germination, GSI, and reduction of RG observed for seeds treated with essential oils of $\mathrm{C} 4$ and $\mathrm{C} 7$ in this study can be justified by the presence of these substances. Essential oils with higher monoterpene content are known for their high ability to suppress weeds (Fagodia et al., 2017). The hydrogenated monoterpene limonene, found mostly in cultivar $\mathrm{C} 4$, is known to blocking the nitrogen cycle and inhibiting cytochrome respiration, seed germination and growth in neighboring plants (Maffei et al., 2011). Limonene is used as a leading compound in various formulations of commercial herbicides, such as GreenMatch O, GreenMatch EX, and Avenger ${ }^{\circledR}$ (Dayan et al., 2009).

Vokou et al. (2003) suggest that the herbicide effect of essential oils is due to the combined reactions of various chemical compounds, which can act in an additive, synergistic, and antagonistic way. In this sense, the herbicide activity found in the essential oils of $P$. guajava cultivars can be attributed mainly to the presence of sesquiterpenes and monoterpenes.

Considering the importance of essential oils due to the great applicability they possess, it is essential to know the chemical compounds present in them, since they are responsible for the phytotherapeutic and biological properties. In larvicidal assays with Aedes aegypti, performed with the essential oils SEC, C4, C6, PAL and PET, the cultivar SEC presented itself as the most efficient for this purpose, which was attributed to a large amount of sesquiterpene present in the oils (Mendes et al., 2017). When comparing this to the results of this study for the cultivar SEC, was observed that the germination of lettuce and sorghum as well as their root growth were affected only when the highest oil concentration $(3000 \mu \mathrm{g} / \mathrm{mL})$ of the oil was used. So, while SEC on the one hand presented high larvicide activity acting on A. aegypti in past studies, our results show that the phytotoxic activity of SEC is less favorable than those of other genotypes. This proves that performing these tests on the potentials of each essential oil, are important to direct them to the most appropriate use.

For all the oils tested the effects were more evident in L. sativa, a eudicot, than S. bicolor, a monocot. Differences in sensitivity among target species are commonly reported in studies that verify the allelopathy and phytotoxicity of plants (Hazrati et al., 2017; Vasconcelos et al., 2019). These differences are related to the variation of the mechanisms of absorption, translocation, and the place of action of substances among different target species, which may explain the differences in selectivity among the species tested in this work (Oliveira Jr., 2011).

\subsection{Cytotoxicity effects}

Cytotoxicity analyses were performed to investigate the toxic effect of the essential oil of $P$. guajava cultivars on the cell cycle of lettuce and to determine the mode of action involved in the inhibition of the germination variables (GP and GSI) and root growth of lettuce and sorghum. Based on MI, as well as NA and CA were founded low cytotoxicity effects of the essential oils of $P$. guajava cultivars when compared to the positive control. The exposure to the highest concentrations of the evaluated oils caused the greatest damage to the meristematic lettuce cells (Table 2). 
Table 2. Analysis of meristematic root cells of Lactuca sativa treated with different concentrations $(\mu \mathrm{g} / \mathrm{mL}) \mathrm{of}$ the essential oil of cultivars of Psidium guajava.

\begin{tabular}{|c|c|c|c|c|}
\hline Cultivar & $\begin{array}{l}\text { Concentration } \\
(\mu \mathrm{g} / \mathrm{mL})\end{array}$ & MI\% & NA\% & CA\% \\
\hline $\mathrm{C} 4$ & $\begin{array}{l}\text { water } \\
\text { glyphosate } \\
187.5 \\
375 \\
750 \\
1500 \\
3000 \\
\end{array}$ & $\begin{array}{c}* 9.60 \pm 0.35 \mathrm{a} \\
2.76 \pm 0.62 \mathrm{~b} \\
8.29 \pm 1.14 \mathrm{a} \\
8.10 \pm 0.49 \mathrm{a} \\
7.83 \pm 0.40 \mathrm{a} \\
8.44 \pm 0.81 \mathrm{a} \\
5.80 \pm 0.92 \\
\end{array}$ & $\begin{array}{c}0.00 \pm 0.00 \mathrm{a} \\
1.03 \pm 0.32 \mathrm{~b} \\
0.00 \pm 0.00 \mathrm{a} \\
0.1 \pm 0.14 \mathrm{a} \\
0.1 \pm 0.14 \mathrm{a} \\
0.06 \pm 0.09 \mathrm{a} \\
0.0 \pm 0.00 \mathrm{a}\end{array}$ & $\begin{array}{c}8.73 \pm 1.63 \mathrm{a} \\
33.15 \pm 7.55 \mathrm{~b} \\
5.83 \pm 4.43 \mathrm{a} \\
9.92 \pm 1.19 \mathrm{a} \\
15.66 \pm 1.84 \mathrm{a} \\
15.21 \pm 2.89 \mathrm{a} \\
22.16 \pm 3.91 \mathrm{~b} \\
\end{array}$ \\
\hline $\mathrm{C} 7$ & $\begin{array}{l}\text { water } \\
\text { glyphosate } \\
187.5 \\
375 \\
750 \\
1500 \\
3000 \\
\end{array}$ & $\begin{array}{l}8.66 \pm 1.10 \mathrm{a} \\
1.58 \pm 0.92 \mathrm{~b} \\
8.00 \pm 2.20 \mathrm{a} \\
7.52 \pm 0.76 \mathrm{a} \\
7.19 \pm 0.79 \mathrm{a} \\
7.14 \pm 1.25 \mathrm{a} \\
6.78 \pm 1.06 \mathrm{a}\end{array}$ & $\begin{array}{c}0.00 \pm 0.00 \mathrm{a} \\
0.06 \pm 0.12 \mathrm{~b} \\
0.08 \pm 0.16 \mathrm{ab} \\
0.00 \pm 0.00 \mathrm{ab} \\
0.00 \pm 0.00 \mathrm{ab} \\
0.74 \pm 1.48 \mathrm{ab} \\
1.00 \pm 0.63 \mathrm{ab}\end{array}$ & $\begin{array}{c}8.79 \pm 5.03 \mathrm{a} \\
13.89 \pm 11.35 \mathrm{~b} \\
17.29 \pm 2.15 \mathrm{ab} \\
16.73 \pm 3.71 \mathrm{ab} \\
14.02 \pm 2.35 \mathrm{ab} \\
15.88 \pm 3.21 \mathrm{ab} \\
19.30 \pm 6.04 \mathrm{ab}\end{array}$ \\
\hline PAL & $\begin{array}{l}\text { water } \\
\text { glyphosate } \\
187.5 \\
375 \\
750 \\
1500 \\
3000 \\
\end{array}$ & $\begin{array}{c}9.7 \pm 0.08 \mathrm{a} \\
1.63 \pm 0.44 \mathrm{~b} \\
9.1 \pm 0.16 \mathrm{a} \\
8.6 \pm 0.24 \mathrm{a} \\
7.23 \pm 0.86 \\
7.06 \pm 1.09 \\
6.46 \pm 0.40 \\
\end{array}$ & $\begin{array}{c}0.00 \pm 0.00 \mathrm{a} \\
0.33 \pm 0.28 \mathrm{~b} \\
0.00 \pm 0.00 \mathrm{ab} \\
0.00 \pm 0.00 \mathrm{ab} \\
0.1 \pm 0.14 \mathrm{ab} \\
0.06 \pm 0.09 \mathrm{ab} \\
0.06 \pm 0.09 \mathrm{ab}\end{array}$ & $\begin{array}{c}11.01 \pm 2.76 \mathrm{a} \\
38.44 \pm 13.76 \mathrm{~b} \\
9.18 \pm 5.18 \mathrm{a} \\
4.57 \pm 3.23 \mathrm{a} \\
15.56 \pm 1.06 \mathrm{a} \\
18.46 \pm 3.71 \mathrm{a} \\
10.70 \pm 3.89 \mathrm{a}\end{array}$ \\
\hline SEC & $\begin{array}{l}\text { water } \\
\text { glyphosate } \\
187.5 \\
375 \\
750 \\
1500 \\
3000\end{array}$ & $\begin{array}{c}9.9 \pm 0.45 \mathrm{a} \\
1.83 \pm 0.65 \mathrm{~b} \\
8.03 \pm 0.28 \\
8.67 \pm 0.18 \mathrm{a} \\
7.49 \pm 0.73 \\
8.93 \pm 0.40 \mathrm{a} \\
8.01 \pm 0.22\end{array}$ & $\begin{array}{c}0.00 \pm 0.00 \mathrm{a} \\
0.1 \pm 0.14 \mathrm{~b} \\
0.00 \pm 0.00 \mathrm{ab} \\
0.00 \pm 0.00 \mathrm{ab} \\
0.1 \pm 0.14 \mathrm{ab} \\
0.16 \pm 0.12 \mathrm{ab} \\
0.00 \pm 0.00 \mathrm{ab}\end{array}$ & $\begin{array}{c}7.79 \pm 1.27 \mathrm{a} \\
47.77 \pm 9.17 \mathrm{~b} \\
7.92 \pm 3.25 \mathrm{a} \\
10.01 \pm 2.78 \mathrm{a} \\
14.26 \pm 0.26 \mathrm{a} \\
16.22 \pm 7.45 \mathrm{a} \\
17.91 \pm 4.16 \mathrm{a}\end{array}$ \\
\hline
\end{tabular}

$\mathrm{MI} \%=$ mitotic index, $\mathrm{CA} \%=$ chromosome alterations out of the total of cells, NA\% = nuclear alterations out of the total of cells. Cultivars: C4 (Cortibel branca LG), C7 (Cortibel 7), PAL (Paluma) and SEC (Século XXI). * Means in the columns followed by the letter a are statistically identical to water, means followed by $\mathrm{b}$ are statistically identical to glyphosate and means not followed by letters are statistically different from water and glyphosate, by Dunnett's test $(\mathrm{p}<0.05)$.

Source: Authors.

In general, MI was the variable most affected by the essential oils, differing statistically from the negative and positive controls at the concentration $3000 \mu \mathrm{g} / \mathrm{mL}$. We could observe a decrease in MI with increasing PAL concentrations, showing a decline at $750(25.47 \%), 1500$ (27.22\%), and $3000 \mu \mathrm{g} / \mathrm{mL}(33.41 \%)$ concerning the negative control. For NA, the negative and positive controls showed little difference, with zero or low frequency of alterations. For CA, only the highest concentration of cultivar C4 showed the statistical difference to the negative control, with an increase of approximately $54 \%$ in alterations. The other tested essential oils were statistically equal to the two controls (C7) or only to the negative control (PAL and SEC). This result may be related to the reduction of the macroscopic variables found in the phytotoxic analyses.

According to Harashima \& Schnittger (2010), cell division and plant growth are associated with cell proliferation, where changes in the cell cycle act directly on the percentage of germination, germination speed index, and root growth. The reduction of $\mathrm{MI}$ is the result of the blockade of the mitotic division, preventing the beginning of the prophase and, consequently, the cell division (Sousa et al., 2009). The MI is a parameter used to indicate the cytotoxic effect of substances (Leme \& Marin-Morales, 2009). MI reduction was also observed in meristematic cells of L. sativa treated with the essential oil of Psidium cattleianum, P. myrtoides, P. friedrichsthalianum and P. gaudichaudianum (Vasconcelos et al., 2019). 
Sesquiterpenes and monoterpenes are allelochemical compounds reported for causing the reduction of mitotic activity and formation of lipid cells in plants, causing inhibition of germination and root growth in several species (Vaughn \& Spencer, 1993). In plants, these substances derived from secondary metabolism act as phytoalexins - substances synthesized anew by plants, and responsible for chemically combating the growth and propagation of parasitic bacteria and fungi (Barbosa et al., 2007).

Table 3 shows the frequency of chromosomal alterations found in the meristematic cells of L. sativa. We observed that the exposure to essential oils caused the occurrence of chromosome loss, chromosomal breaks, adherent chromosomes, cmetaphases and bridges (Figure 5). A significant increase in the frequency of alterations, however, was observed only at the highest concentrations. Cultivar C4 caused the highest frequency of adherent chromosomes at a concentration of $1500 \mu \mathrm{g} / \mathrm{mL}$ and of bridges at $3000 \mu \mathrm{g} / \mathrm{mL}$, differing from the negative control. In C7, the highest concentration of the oil ( $3000 \mu \mathrm{g} / \mathrm{mL})$ led to an increase in the frequency of c-metaphases, but without being statistically different from the positive control. The oil of the PAL cultivar led to an increase in the percentage of adherent chromosomes in relation to the negative control at concentrations of 750 and $1500 \mu \mathrm{g} / \mathrm{mL}$. The SEC oil led to the increase of adherent chromosomes and bridges concerning the negative control at the highest concentration. For chromosome breaking, chromosomal alterations and lost chromosomes, all essential oils caused very low or zero frequencies and were statistically not different from negative and positive control.

Figure 5. Examples of the main cell cycle alterations in meristematic cells of Lactuca sativa exposed to different concentrations of the essential oils of the cultivars of Psidium guajava. (a) and (b) anaphase with bridge, (c) telophase with bridge, (d) chromosomic fragment in anaphase, (e) chromosome loss and (f) adherent chromosome.

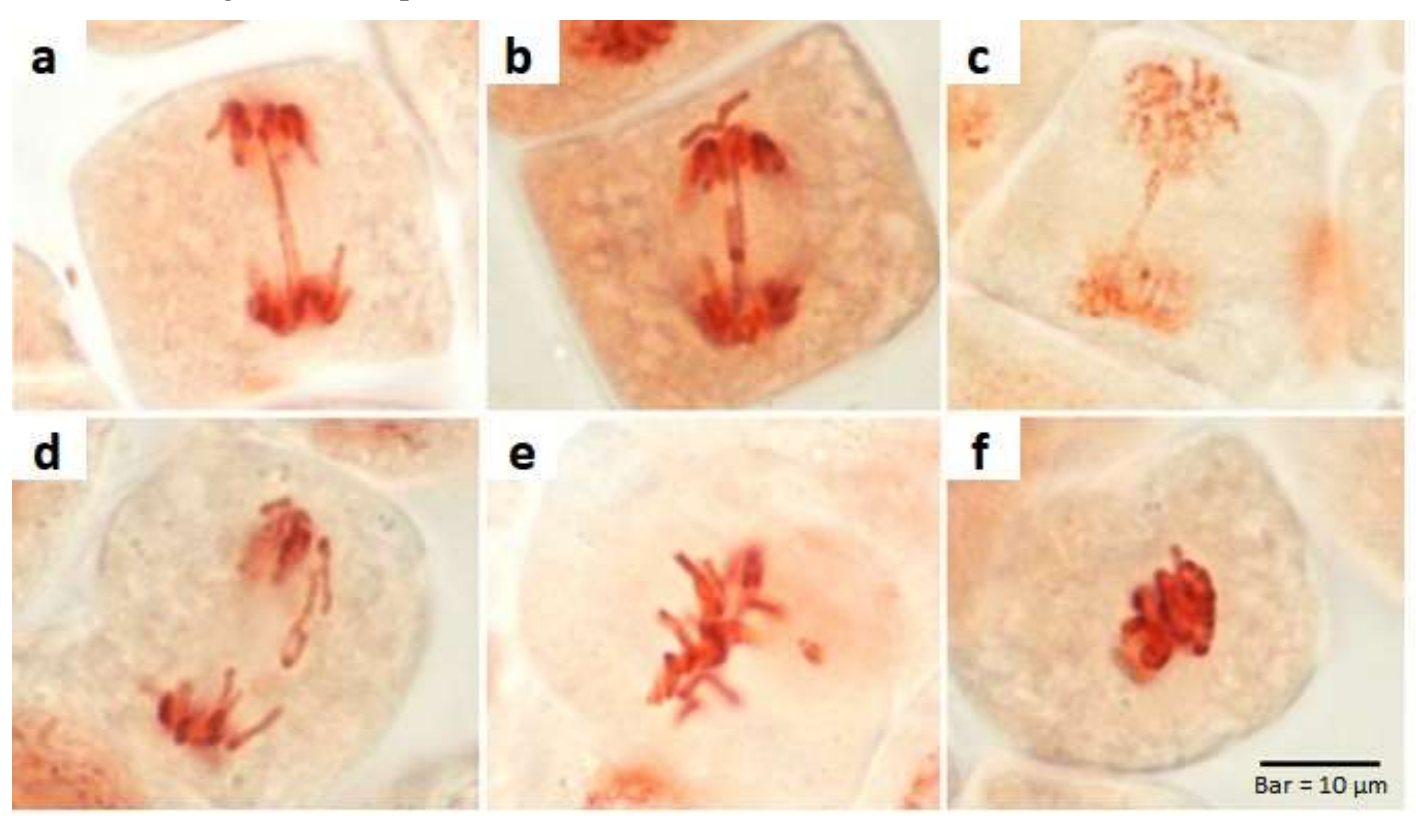

Source: Authors. 
Table 3. Chromosomal alterations observed in meristematic root cells of Lactuca sativa treated with different concentrations of the essential oil of cultivars of Psidium guajava.

\begin{tabular}{|c|c|c|c|c|c|c|}
\hline Cultivar & $\begin{array}{c}\text { Concentration } \\
(\mu \mathrm{g} / \mathrm{mL})\end{array}$ & Lost $\%$ & Breakage\% & Adherent $\%$ & C-met $\%$ & Bridge $\%$ \\
\hline \multirow[t]{7}{*}{$\mathrm{C} 4$} & water & $* 0.00 \pm 0.00 \mathrm{a}$ & $0.00 \pm 0.00 \mathrm{a}$ & $0.36 \pm 0.51 \mathrm{a}$ & $6.99 \pm 1.27 \mathrm{a}$ & $1.04 \pm 1.21 \mathrm{a}$ \\
\hline & glyphosate & $2.51 \pm 1.95 b$ & $0.00 \pm 0.00 \mathrm{~b}$ & $0.00 \pm 0.00 \mathrm{~b}$ & $26.84 \pm 9.98 b$ & $1.28 \pm 1.81 \mathrm{~b}$ \\
\hline & 187.5 & $0.73 \pm 0.51 \mathrm{ab}$ & $0.00 \pm 0.00 \mathrm{ab}$ & $1.48 \pm 1.40 \mathrm{ab}$ & $2.88 \pm 3.31 \mathrm{a}$ & $2.39 \pm 0.50 \mathrm{ab}$ \\
\hline & 375 & $0.00 \pm 0.00 \mathrm{ab}$ & $0.00 \pm 0.00 \mathrm{ab}$ & $3.31 \pm 1.52 \mathrm{a}$ & $5.31 \pm 3.05 \mathrm{a}$ & $1.23 \pm 1.10 \mathrm{ab}$ \\
\hline & 750 & $1.23 \pm 0.97 \mathrm{ab}$ & $0.88 \pm 0.00 \mathrm{ab}$ & $3.34 \pm 1.46 \mathrm{a}$ & $6.80 \pm 1.14 \mathrm{a}$ & $1.29 \pm 0.97 \mathrm{ab}$ \\
\hline & 1500 & $0.00 \pm 0.00 \mathrm{ab}$ & $0.00 \pm 0.00 \mathrm{ab}$ & $6.68 \pm 1.15$ & $5.28 \pm 1.52 \mathrm{a}$ & $0.35 \pm 0.21 \mathrm{ab}$ \\
\hline & 3000 & $0.74 \pm 1.04 \mathrm{ab}$ & $0.52 \pm 0.74 \mathrm{ab}$ & $3.04 \pm 1.19 \mathrm{ab}$ & $13.79 \pm 2.81 \mathrm{a}$ & $4.05 \pm 0.62$ \\
\hline \multirow[t]{7}{*}{$\mathrm{C} 7$} & water & $0.00 \pm 0.00 \mathrm{a}$ & $0.00 \pm 0.00 \mathrm{a}$ & $1.60 \pm 2.19 \mathrm{a}$ & $5.87 \pm 3.34 \mathrm{a}$ & $1.08 \pm 0.66 \mathrm{a}$ \\
\hline & glyphosate & $0.90 \pm 1.81 \mathrm{~b}$ & $0.00 \pm 0.00 \mathrm{~b}$ & $0.00 \pm 0.00 \mathrm{~b}$ & $12.98 \pm 10.77 b$ & $0.00 \pm 0.00 \mathrm{~b}$ \\
\hline & 187.5 & $0.21 \pm 0.43 \mathrm{ab}$ & $0.55 \pm 1.11 \mathrm{ab}$ & $1.76 \pm 2.06 \mathrm{ab}$ & $11.00 \pm 1.31 \mathrm{ab}$ & $2.21 \pm 1.87 \mathrm{ab}$ \\
\hline & 375 & $0.24 \pm 0.48 \mathrm{ab}$ & $0.24 \pm 0.49 \mathrm{ab}$ & $2.07 \pm 2.28 \mathrm{ab}$ & $10.03 \pm 2.39 \mathrm{ab}$ & $2.35 \pm 1.60 \mathrm{ab}$ \\
\hline & 750 & $0.00 \pm 0.00 \mathrm{ab}$ & $0.63 \pm 1.26 \mathrm{ab}$ & $0.89 \pm 1.21 \mathrm{ab}$ & $10.76 \pm 3.02 \mathrm{ab}$ & $0.57 \pm 0.70 \mathrm{ab}$ \\
\hline & 1500 & $0.00 \pm 0.00 \mathrm{ab}$ & $0.46 \pm 0.93 \mathrm{ab}$ & $0.79 \pm 0.65 \mathrm{ab}$ & $11.09 \pm 1.79 \mathrm{ab}$ & $2.71 \pm 2.86 \mathrm{ab}$ \\
\hline & 3000 & $0.00 \pm 0.00 \mathrm{ab}$ & $1.05 \pm 2.10 \mathrm{ab}$ & $0.92 \pm 0.80 \mathrm{ab}$ & $14.70 \pm 3.98 b$ & $1.43 \pm 1.29 \mathrm{ab}$ \\
\hline \multirow[t]{7}{*}{ PAL } & water & $0.00 \pm 0.00 \mathrm{a}$ & $0.00 \pm 0.00 \mathrm{a}$ & $0.68 \pm 0.97 \mathrm{a}$ & $8.94 \pm 1.99 \mathrm{a}$ & $1.37 \pm 0.73 \mathrm{a}$ \\
\hline & glyphosate & $0.00 \pm 0.00 \mathrm{~b}$ & $0.00 \pm 0.00 \mathrm{~b}$ & $0.00 \pm 0.00 \mathrm{~b}$ & $35.41 \pm 14.84 b$ & $0.00 \pm 0.00 b$ \\
\hline & 187.5 & $0.00 \pm 0.00 \mathrm{ab}$ & $0.00 \pm 0.00 \mathrm{ab}$ & $2.93 \pm 1.40 \mathrm{a}$ & $7.19 \pm 3.22$ & $0.35 \pm 0.50 \mathrm{ab}$ \\
\hline & 375 & $0.38 \pm 0.54 \mathrm{ab}$ & $0.37 \pm 0.52 \mathrm{ab}$ & $0.38 \pm 0.54 \mathrm{ab}$ & $3.03 \pm 2.31$ & $0.00 \pm 0.00 \mathrm{ab}$ \\
\hline & 750 & $0.90 \pm 1.27 \mathrm{ab}$ & $0.00 \pm 0.00 \mathrm{ab}$ & $4.21 \pm 0.52$ & $9.5 \pm 1.90 \mathrm{a}$ & $0.40 \pm 0.57 \mathrm{ab}$ \\
\hline & 1500 & $1.09 \pm 1.54 \mathrm{ab}$ & $1.53 \pm 2.17 \mathrm{ab}$ & $6.27 \pm 2.14$ & $6.91 \pm 3.22 \mathrm{a}$ & $0.77 \pm 1.09 \mathrm{ab}$ \\
\hline & 3000 & $0.49 \pm 0.69 \mathrm{ab}$ & $0.00 \pm 0.00 \mathrm{ab}$ & $1.96 \pm 1.83 \mathrm{ab}$ & $7.19 \pm 1.20 \mathrm{a}$ & $0.49 \pm 0.69 \mathrm{ab}$ \\
\hline \multirow[t]{7}{*}{ SEC } & water & $0.31 \pm 0.44 \mathrm{a}$ & $0.00 \pm 0.00 \mathrm{a}$ & $0.70 \pm 1.00 \mathrm{a}$ & $7.50 \pm 2.00 \mathrm{a}$ & $1.04 \pm 0.86 \mathrm{a}$ \\
\hline & glyphosate & $1.96 \pm 2.77 b$ & $0.00 \pm 0.00 \mathrm{~b}$ & $1.23 \pm 1.74 \mathrm{~b}$ & $39.59 \pm 8.77 b$ & $1.96 \pm 2.77 b$ \\
\hline & 187.5 & $0.39 \pm 0.56 \mathrm{ab}$ & $0.00 \pm 0.00 \mathrm{ab}$ & $2.12 \pm 2.22 \mathrm{ab}$ & $5.00 \pm 1.13$ & $0.00 \pm 0.00 \mathrm{ab}$ \\
\hline & 375 & $0.76 \pm 0.53 \mathrm{ab}$ & $0.00 \pm 0.00 \mathrm{ab}$ & $2.33 \pm 1.67 \mathrm{ab}$ & $5.00 \pm 3.06$ & $1.52 \pm 0.50 \mathrm{ab}$ \\
\hline & 750 & $0.83 \pm 0.59 \mathrm{ab}$ & $0.52 \pm 0.73 a b$ & $3.65 \pm 0.92 \mathrm{ab}$ & $7.51 \pm 1.12 \mathrm{a}$ & $1.33 \pm 1.00 \mathrm{ab}$ \\
\hline & 1500 & $1.16 \pm 1.64 \mathrm{ab}$ & $0.00 \pm 0.00 \mathrm{ab}$ & $4.11 \pm 2.38 \mathrm{ab}$ & $8.23 \pm 0.80 a$ & $1.15 \pm 0.94 \mathrm{ab}$ \\
\hline & 3000 & $0.74 \pm 1.04 \mathrm{ab}$ & $0.52 \pm 0.74 \mathrm{ab}$ & $3.04 \pm 1.19 \mathrm{ab}$ & $13.79 \pm 2.81$ & $4.05 \pm 0.62 b$ \\
\hline
\end{tabular}

Lost $\%=$ chromosome loss, Breakage $\%=$ chromosomal breaks, Adherent $\%=$ adherent chromosomes, C-met $\%=$ c-metaphases and Bridge $\%$ = chromosome bridges. Cultivars: C4 (Cortibel branca LG), C7 (Cortibel 7), PAL (Paluma) and SEC (Século XXI).*Means in the columns followed by the letter a are statistically identical to water, means followed by b are statistically identical to glyphosate and means not followed by letters are statistically different from water and glyphosate, by Dunnett's test $(\mathrm{p}<0.05)$.

Source: Authors.

The presence of chromosomal alterations shows the genotoxic effect while the nuclear alterations show the mutagenic effect, these alterations modify the structure and/or quantity of chromosomes (Fiskesjö, 1985). In this study, it was possible to observe a higher incidence of chromosomal alterations of the bridge type, c-metaphase, and adherent chromosomes, demonstrating the genotoxic effect of essential oils.

Chromosomal bridges are clastogenic alterations that indicate some action in the structure of the DNA. They usually occur in anaphase and telophase and are related to terminal breaks (telomere loss) in both chromatids of a chromosome followed by the union of the same (Leme \& Marin-Morales, 2009; Matsumoto et al., 2006). The adherent chromosomes and cmetaphases are alterations that indicate the aneugenic mode of action. The adherent chromosomes reflect a change in the chromosomal structure, leading to the loss of the normal characteristics of condensation and the formation of agglomerates. This change is irreversible and can lead to cell death, thus evidencing a strong cytotoxic effect (Babich, 1997; El-Ghamery et al., 2003). The c-metaphases are alterations that point to the action toxic compounds in the spindle fibers, paralyzing the mitotic cycle in metaphase. This alteration is characterized by scattered and condensed chromosomes with very well-defined centromeres in the interior of the cell (Fiskesjö, 1985; Leme \& Marin-Morales, 2009). 
Essential oils of cultivars C4 and SEC presented both modes of action, aneugenic and clastogenic since was observed a higher frequency of alterations of type bridges, adherent chromosomes, and c-metaphase compared to the negative control. The essential oils of C7 and PAL presented a higher frequency of chromosomes in c-metaphase, characterizing them as aneugenic essential oil. Given the above, the terpene constitution of essential oils and the interactions between these compounds inducing several chromosomal abnormalities, which are responsible for inhibition of germination, germination speed index and root growth of the model plants.

\section{Conclusions}

This study showed the allelopathic potential of $P$. guajava cultivars essential oils in plant bioassays lettuce and sorghum. The effects were more evident in L. sativa than S. bicolor, demonstrating greater sensitivity of lettuce to the tested compounds. The exposure of the tested species to the essential oils caused the reduction of germination, root growth, and mitotic index in L. sativa. In general, the highest concentrations $(3000 \mu \mathrm{g} / \mathrm{mL})$ of the oils caused more evident effects in the analyses performed.

We also observed an increase in the percentage of chromosomal changes, such as bridges, c-metaphase and adherent chromosome in L. sativa meristematic cells. These alterations reveal the aneugenic and clastogenic mode of action associated with the oils. Phytotoxic, cytotoxic and genotoxic activity of essential oils may be associated with the terpene constitution of essential oils and the interactions between these compounds, mainly by the presence of caryophyllene oxide, (E)-caryophyllene and limonene. Given the above, the essential oils of guava cultivars are potential sources for the development of natural and sustainable herbicides due to their inhibitory activity in plants.

\section{Acknowledgments}

We would like to thank the Conselho Nacional de Desenvolvimento Científico e Tecnológico (CNPq, Brasília—DF, Brazil; Grants 311950/2016-7), Fundação de Amparo à Pesquisa do Espírito Santo (FAPES/VALE, Vitória-ES, Brazil; Grant 75516586/16 and FAPES/UNIVERSAL, Vitória-ES, Brazil; Grant 180/2017 and 80707114/18). This study was financed in part by the Coordernação de Aperfeiçoamento de Pessoal de Nível Superior_Brasil (CAPES)—Finance Code 001.

\section{References}

Adams, R. P. (2007). Identification of essential oil components by gas chromatography/mass spectrometry (Ed. 4). Allured Publishing Corporation.

Almeida, L., Teixeira, M. C., Lemos, J. R., Lacerda, M. N., \& Silva, T. C. (2019). Bioatividade de óleos essenciais na germinação e no vigor em sementes de tomate. Biotemas, 32(2), 13-21.

Alves, T. de A., Pinheiro, P. F., Fontes, M. M. P., Andrade-Vieira, L. F., Corrêa, K. B., Alves, T. A., Cruz, F. A., Júnior, V. L., Ferreira, A., \& Soares, T. C. B. (2018). Toxicity of thymol, carvacrol and their respective phenoxyacetic acids in Lactuca sativa and Sorghum bicolor. Industrial Crops and Products, 114, 59-67. https://doi.org/10.1016/j.indcrop.2018.01.071

Amri, I., Hamrouni, L., Hanana, M., Gargouri, S., Fezzani, T., \& Jamoussi, B. (2013). Chemical composition, physico-chemical properties, antifungal and herbicidal activities of Pinus halepensis Miller essential oils. Biological Agriculture and Horticulture, 29(2), 91-106. https://doi.org/10.1080/01448765.2013.764486

Andrade-Vieira, L. F., Botelho, C. M., Palmieri, M.J., Laviola, B. G., \& Praça-Fontes, M. M. (2014). Effects of Jatropha curcas oil in Lactuca sativa root tip bioassays. Anais da Academia Braseleira de Ciências, 86(1), 373-382. http://dx.doi.org/10.1590/0001-3765201420130041

Aragão, F. B., Queiroz, V. T., Ferreira, A., Costa, A. V., Pinheiro, P. F., Carrijo, T. T., \& Andrade-Vieira, L. F. (2017). Phytotoxicity and cytotoxicity of Lepidaploa rufogrisea (Asteraceae) extracts in the plant model Lactuca sativa (Asteraceae). Revista de Biologia Tropical, 65(2) 1-10. https://doi.org/10.15517/rbt.v65i2.25696

Araniti, F., Graña, E., Krasuska, U., Bogatek, R., Reigosa, M. J., Abenavoli, M. R., \& Sánchez-Moreiras, A. M. (2016). Loss of gravitropism in farnesenetreated arabidopsis is due to microtubule malformations related to hormonal and ROS unbalance. PLoS ONE, 11(8), 1-26. https://doi.org/10.1371/journal.pone.0160202 
Aslam, F., Khaliq, A., Matloob, A., Tanveer, A., Hussain, S., \& Zahir, Z. A. (2017). Allelopathy in agro-ecosystems: a critical review of wheat allelopathyconcepts and implications. Chemoecology, 27(1). https://doi.org/10.1007/s00049-016-0225-x

Babich, H. (1997). The "Allium" test: A simple, eukaryote genotoxicity assay. The American Biology Teacher, 59(9), 580-583. https://doi.org/10.2307/4450386

Barbosa, L. C. A., Demuner, A. J., Clemente, A. D., Paula, V. F., \& Ismail, F. M. D. (2007). Seasonal variation in the composition of volatile oils from Schinus terebinthifolius Raddi. Quimica Nova, 30(8), 1959-1965. https://doi.org/10.1590/S0100-40422007000800030

Beech, E., Rivers, M., Oldfield, S., \& Smith, P. P. (2017). GlobalTreeSearch: the first complete global database of tree species and country distributions. Journal of Sustainable Forestry, 36, 454-489. https://doi.org/10.1080/10549811.2017.1310049

Boaro, C. S. F., Vieira, M. A. R., Campos, F. G., Ferreira, G., Chacón, I. D. C., \& Marques, M. O. M. (2019). Factors influencing the production and chemical composition of essential oils in aromatic plants from Brazil. Essential Oil Research, 19-47. https://doi.org/10.1007/978-3-030-16546-8_2

Caputo, L., Smeriglio, A., Trombetta, D., Cornara, L., Trevena, G., Valussi, M., Fratianni, F., Feo, V., \& Nazzaro, F. (2020). Chemical composition and biological activities of the essential oils of Leptospermum petersonii and Eucalyptus gunnii. Frontiers in Microbiology, 11, 1-15. https://doi.org/10.3389/fmicb.2020.00409

Chaturvedi, T., Singh, S., Nishad, I., Kumar, A., Tiwari, N., Tandon, S., Saikia, D., \& Verma, R. S. (2019). Chemical composition and antimicrobial activity of the essential oil of senescent leaves of guava (Psidium guajava L.). Natural Product Research, 35, 1393-1397. https://doi.org/10.1080/14786419.2019.1648462

Dayan, F. E., Cantrell, C. L., \& Duke, S. O. (2009). Natural products in crop protection. Bioorganic and Medicinal Chemistry, 17(12), 4022-4034. https://doi.org/10.1016/j.bmc.2009.01.046

Dayan, F. E., \& Duke, S. O. (2014). Natural compounds as next-generation herbicides. Plant Physiology, 166(3), 1090-1105. https://doi.org/10.1104/pp.114.239061

Dias, J. D. F. G., Miguel, O. G., \& Miguel, M. D. (2009). Composition of essential oil and allelopathic activity of aromatic water of Aster lanceolatus Willd. (Asteraceae). Brazilian Journal of Pharmaceutical Sciences, 45(3), 469-474. https://doi.org/10.1590/S1984-82502009000300012

Duke, S. O., \& Oliva, A. (2004). Mode of action of phytotoxic terpenoids. In H. Macias, F., Galindo, J., Molinillo, J., Cutler (Ed.), Allelopathy: Chemistry and mode of action of allelochemicals. CRC Press. https://doi.org/10.1201/9780203492789.ch10

Duke, Stephen O., Romagni, J. G., \& Dayan, F. E. (2000). Natural products as sources for new mechanisms of herbicidal action. Crop Protection, 19, 583589. https://doi.org/10.1016/S0261-2194(00)00076-4

Durazzini, A. M. S., Machado, C. H. M., Fernandes, C. C., Willrich, G. B., Crotti, A. E. M., Candido, A. C. B. B., Magalhães, L. G., Squarisi, I. S., Ribeiro, A. B., Tavares, D. C., Martins, C. H. G., \& Miranda, M. L. D. (2019). Eugenia pyriformis Cambess: a species of the Myrtaceae family with bioactive essential oil. Natural Product Research. https://doi.org/10.1080/14786419.2019.1669031

El-Ghamery, A. A., El-Kholy, M. A., \& Abou El-Yousser, M. A. (2003). Evaluation of cytological effects of Zn2+ in relation to germination and root growth of Nigella sativa L. and Triticum aestivum L. Mutation Research - Genetic Toxicology and Environmental Mutagenesis, 537, $29-41$. https://doi.org/10.1016/S1383-5718(03)00052-4

Fagodia, S. K., Singh, H. P., Batish, D. R., \& Kohli, R. K. (2017). Phytotoxicity and cytotoxicity of Citrus aurantiifolia essential oil and its major constituents: Limonene and citral. Industrial Crops and Products, 108, 708-715. https://doi.org/10.1016/j.indcrop.2017.07.005

Fiskesjö, G. (1985). The Allium test as a standard in environmental monitoring. Hereditas, 102(1), 99-112. https://doi.org/10.1111/j.16015223.1985.tb00471.x

Giunti, G., Campolo, O., Laudani, F., Zappalà, L., \& Palmeri, V. (2021). Bioactivity of essential oil-based nano-biopesticides toward Rhyzopertha dominica (Coleoptera: Bostrichidae). Industrial Crops and Products, 162, 113257. https://doi.org/10.1016/j.indcrop.2021.113257

Grul’ová, D., Caputo, L., Elshafie, H. S., Baranová, B., De Martino, L., Sedlák, V., Gogalová, Z., Poráčová, J., Camele, I., \& Feo, V. (2020). Thymol chemotype Origanum vulgare L. essential oil as a potential selective bio-based herbicide on monocot plant species. Molecules, $25(3), 595$. https://doi.org/10.3390/molecules25030595

Habermann, E., Pereira, V. D. C., Imatomi, M., Pontes, F. C. \& Gualtieri, S. C. J. (2017). In vitro herbicide activity of crude and fractionated leaf extracts of Blepharocalyx salicifolius (Myrtaceae). Brazilian Journal of Botany, 40, 33-40. https://doi.org/10.1007/s40415-016-0317-4

Harashima, H., \& Schnittger, A. (2010). The integration of cell division, growth and differentiation. Current Opinion in Plant Biology, 13(1), 66-74. https://doi.org/10.1016/j.pbi.2009.11.001

Harborne, J. B., \& Tomas-Barberan, F. A. (1990). Ecological chemistry and biochemistry of plant terpenoids. Clarendon Press.

Hayes, W. B. (1953). Fruit Growing in India. Allahabad.

Hazrati, H., Saharkhiz, M. J., Niakousari, M., \& Moein, M. (2017). Natural herbicide activity of Satureja hortensis L. essential oil nanoemulsion on the seed germination and morphophysiological features of two important weed species. Ecotoxicology and Environmental Safety, 142, 423-430. https://doi.org/10.1016/j.ecoenv.2017.04.041

Ibrahim, M., Farooq, T., Hussain, N., Hussain, A., Gulzar, T., Hussain, I., Akash, M. S., \& Rehmani, F. S. (2013). Acetyl and butyryl cholinesterase inhibitory sesquiterpene lactones from Amberboa ramosa. Chemistry Central Journal, 7(1), 3-7. https://doi.org/10.1186/1752-153X-7-116 
Inderjit, Wardle, D. A., Karban, R., \& Callaway, R. M. (2011). The ecosystem and evolutionary contexts of allelopathy. Trends in Ecology and Evolution, 26, 655-662. https://doi.org/10.1016/j.tree.2011.08.003

Jabran, K., Mahajan, G., Sardana, V., \& Chauhan, B. S. (2015). Allelopathy for weed control in agricultural systems. Crop Protection, 72, 57-65. https://doi.org/10.1016/j.cropro.2015.03.004

Jana, A., \& Biswas, S. M. (2011). Lactam nonanic acid, a new substance from Cleome viscosa with allelopathic and antimicrobial properties. Journal of Biosciences, 36(1), 27-35. https://doi.org/10.1007/s12038-011-9001-9

Jerônimo, L. B., da Costa, J. S., Pinto, L. C., Montenegro, R. C., Setzer, W. N., Mourão, R. H. V., da Silva, J. K. R., Maia, J. G. S., \& Figueiredo, P. L. B. (2021). Antioxidant and cytotoxic activities of Myrtaceae essential oils rich in terpenoids from Brazil. Natural Product Communications, 16(2), 1934578X2199615. https://doi.org/10.1177/1934578X21996156

Khadhri, A., El Mokni, R., Almeida, C., Nogueira, J. M. F., \& Araújo, M. E. M. (2014). Chemical composition of essential oil of Psidium guajava L. growing in Tunisia. Industrial Crops and Products, 52, 29-31. https://doi.org/10.1016/j.indcrop.2013.10.018

Lee, W. C., Mahmud, R., Noordin, R., Pillai Piaru, S., Perumal, S., \& Ismail, S. (2013). Free radicals scavenging activity, cytotoxicity and anti-parasitic activity of essential oil of Psidium guajava L. leaves against Toxoplasma gondii. Journal of Essential Oil-Bearing Plants, 16(1), 32-38. https://doi.org/10.1080/0972060X.2013.764196

Leme, D. M., \& Marin-Morales, M. A. (2009). Allium cepa test in environmental monitoring: A review on its application. Mutation Research - Reviews in Mutation Research, 682, 71-81. https://doi.org/10.1016/j.mrrev.2009.06.002

Nist standard reference database 69. (2011). NIST Chemistry WebBook. https://webbook.nist.gov/chemistry.

Maffei, M. E., Gertsch, J., \& Appendino, G. (2011). Plant volatiles: production, function and pharmacology. Natural Product Reports, 28(8), 1359-1380. https://doi.org/10.1039/c1np00021g

Matoba, H., Mizutani, T., Nagano, K., Hoshi, Y., \& Uchiyama, H. (2007). Chromosomal study of lettuce and its allied species (Lactuca spp., Asteraceae) by means of karyotype analysis and fluorescence in situ hybridization. Hereditas, 144(6), 235-243. https://doi.org/10.1111/j.2007.0018-0661.02012x

Matsumoto, S. T., Mantovani, M. S., Malaguttii, M. I. A., Dias, A. L., Fonseca, I. C., \& Marin-Morales, M. A. (2006). Genotoxicity and mutagenicity of water contaminated with tannery effluents as evaluated by the micronucleus test and comet assay using the fish Oreochromis niloticus and chromosome aberrations in onion root-tips. Genetics and Molecular Biology, 29, 148-158. https://doi.org/10.1590/S1415-47572006000100028

Mendes, L. A., Martins, G. F., Valbon, W. R., Souza, T. S., Menini, L., Ferreira, A., \& Ferreira, M. F. S. (2017). Larvicidal effect of essential oils from Brazilian cultivars of guava on Aedes aegypti L. Industrial Crops and Products, 108, 684-689. https://doi.org/10.1016/j.indcrop.2017.07.034

Navarro-Rocha, J., Andrés, M. F., Díaz, C. E., Burillo, J., \& González-Coloma, A. (2020). Composition and biocidal properties of essential oil from predomesticated spanish Satureja montana. Industrial Crops and Products, 145, 111958. https://doi.org/10.1016/j.indcrop.2019.111958

Oliveira Jr., R. S. (2011). Mecanismos de Ação de Herbicidas in Biologia e Manejo de plantas Daninhas. Omnipax.

Pinheiro, P. F., Costa, A. V., Alves, T. A., Galter, I. N., Pinheiro, C. A., Pereira, A. F., Oliveira, C. M. R., \& Fontes, M. M. P. (2015). Phytotoxicity and cytotoxicity of essential oil from leaves of Plectranthus amboinicus, carvacrol, and thymol in plant bioassays. Journal of Agricultural and Food Chemistry, 63(41), 8981-8990. https://doi.org/10.1021/acs.jafc.5b03049

R Development Core Team. (2020). R: A language and environment for statistical computing. R Foundation for Statistical Computing, Vienna, Austria. http://www.R-project.org/

Rajkumar, V., Gunasekaran, C., Paul, C. A., \& Dharmaraj, J. (2020). Development of encapsulated peppermint essential oil in chitosan nanoparticles: characterization and biological efficacy against stored-grain pest control. Pesticide Biochemistry and Physiology, 170, 104679. https://doi.org/10.1016/j.pestbp.2020.104679

Ribas, P. P., \& Matsumura, A. T. S. (2009). A química dos agrotóxicos: impacto sobre a saúde e meio ambiente. Revista Liberato, 10(14), 149-158. https://doi.org/10.31514/rliberato.2009v10n14.p149

Rice, E. L. (2012). Allelopathy. Academic press.

Ruilong, W., Shaolin, P., Rensen, Z., Ling, W. D., \& Zengfu, X. U. (2009). Cloning, expression and wounding induction of $\beta$-caryophyllene synthase gene from Mikania micrantha H.B.K. and allelopathic potential of $\beta$-caryophyllene. Allelopathy Journal, 24(1), 35-44.

Satyal, P., Paudel, P., Lamichhane, B., \& Setzer, W. N. (2015). Leaf essential oil composition and bioactivity of Psidium guajava from Kathmandu, Nepal. American Journal of Essential Oils and Natural Products, 3(2), 11-14.

Sousa, S. M., Silva, P. S., Campos, J. M. S., \& Viccini, L. F. (2009). Cytotoxic and genotoxic effects of two medicinal species of Verbenaceae. Caryologia, 62(4), 326-333 https://doi.org/10.1080/00087114.2004.10589698

Scalvenzi, L., Grandini, A., Spagnoletti, A., Tacchini, M., Neill, D., Ballesteros, J., Sacchetti, G., \& Guerrini, A. (2017). Myrcia splendens (Sw.) DC. (syn. M. fallax (Rich.) DC.) (Myrtaceae) essential oil from Amazonian Ecuador: a chemical characterization and bioactivity profile. Molecules, $22(7)$, 1163. https://doi.org/10.3390/molecules22071163

Sharifi-Rad, J., Sureda, A., Tenore, G. C., Daglia, M., Sharifi-Rad, M., Valussi, M., Tundis, R., Sharifi-Rad, M., Loizzo, M. R., Ademiluyi, A. O., Sharifi-Rad, R., Ayatollahi, S. A., \& Iriti, M. (2017). Biological activities of essential oils: From plant chemoecology to traditional healing systems. Molecules, $22,70$. https://doi.org/10.3390/molecules22010070 
Research, Society and Development, v. 10, n. 9, e6110917710, 2021

(CC BY 4.0) | ISSN 2525-3409 | DOI: http://dx.doi.org/10.33448/rsd-v10i9.17710

Shu, J. C., Liu, J. Q., Chou, G. X., \& Wang, Z. T. (2012). Two new triterpenoids from Psidium guajava. Chinese Chemical Letters, 23(7), 827-830. https://doi.org/10.1016/j.cclet.2012.05.018

Silveira, G. L., Lima, M. G. F., Dos Reis, G. B., Palmieri, M. J. \& Andrade-Vieira, L. F. (2017). Toxic effects of environmental pollutants: Comparative investigation using Allium cepa L. and Lactuca sativa L. Chemosphere, 178, 359-367. https://doi.org/10.1016/j.chemosphere.2017.03.048

Soliman, F. M., Fathy, M. M., Salama, M. M., \& Saber, F. R. (2016). Comparative study of the volatile oil content and antimicrobial activity of Psidium guajava L. and Psidium cattleianum Sabine leaves. Bulletin of Faculty of Pharmacy, Cairo University, 54(2), 219-225. https://doi.org/10.1016/j.bfopcu.2016.06.003

Souza, T. S., Ferreira, Ferreira, M. S. F., Menini, L., Souza, J. R. C. L., Parreira, L. A., Cecon, P. R., \& Ferreira, A. (2017). Essential oil of Psidium guajava: Influence of genotypes and environment. Scientia Horticulturae, 216, 38-44. https://doi.org/10.1016/j.scienta.2016.12.026

Taban, A., Saharkhiz, M. J., \& Naderi, R. (2020). A natural post-emergence herbicide based on essential oil encapsulation by cross-linked biopolymers: characterization and herbicidal activity. Environmental Science and Pollution Research, 27(36), 45844-45858. https://doi.org/10.1007/s11356-020-10405-y

Vasconcelos, L. C., Santos, E. S., Bernardes, C. O., Ferreira, M. F. S., Ferreira, A., Tuler, A. C., Carvalho, J. A. M., Pinheiro, P. F., \& Praça-Fontes, M. M. (2019). Phytochemical analysis and effect of the essential oil of Psidium L. species on the initial development and mitotic activity of plants. Environmental Science and Pollution Research, 26, 26216-26228. https://doi.org/10.1007/s11356-019-05912-6

Vaughn, S. F., \& Spencer, G. F. (1993). Volatile monoterpenes as potential parent structures for new herbicides. Weed Science, 41, 114-119. https://doi.org/10.1017/s0043174500057672

Vokou, D., Douvli, P., Blionis, G. J., \& Halley, J. M. (2003). Effects of monoterpenoids, acting alone or in pairs, on seed germination and subsequent seedling growth. Journal of Chemical Ecology, 29(10), 2281-2301. https://doi.org/10.1023/A:1026274430898

Weli, A., Al-Kaabi, A., Al-Sabahi, J., Said, S., Hossain, M. A., \& Al-Riyami, S. (2019). Chemical composition and biological activities of the essential oils of Psidium guajava leaf. Journal of King Saud University - Science, 31(4), 993-998. https://doi.org/10.1016/j.jksus.2018.07.021

Wilson, P. G. (2010). Myrtaceae in Flowering Plants. Eudicots. The Families and Genera of Vascular Plants. Springer. 